\title{
Entrepreneurial Behaviour of Dairy Farmers in North-Western Rajasthan
}

\author{
Dwarka Prasad $^{1 *}$, J. P. Lakhera ${ }^{2}$, Seema Tyagi ${ }^{3}$, Diksha Sharma ${ }^{1}$ and Sunil Kumar ${ }^{4}$ \\ ${ }^{1}$ Agriculture Extension \& Communication, College of Agriculture, Bikaner, India \\ ${ }^{2}$ Director (Ext. Edn.), ${ }^{3}$ Home Science Extension and Communication Management, SKRAU, \\ Bikaner, India \\ ${ }^{4}$ Dairy Ext. Edn., ICAR-NDRI, Karnal, India \\ *Corresponding author
}

\section{A B S T R A C T}

\section{Keywords}

Dairy farmers, Entrepreneurial behaviour

Article Info

Accepted:

10 January 2021

Available Online:

10 February 2021
Dairy farming is a crucial component of rural economy that has the highest potential of generating income and employment through augmenting productivity of milch animals. It is one of the promising sectors for entrepreneurship development in India. Entrepreneurship has been accepted globally as affective tool for widening the entrepreneurial base for those who have poor financial resources or managerial background. Thus, entrepreneurship development in rural area appears to be best possible alternatives to find employment avenues for the rural population. The present investigation was confined to two milk union viz., Ganganagar and Bikaner were purposely selected for study due to reason that these milk unions had higher number of registered dairy cooperative societies (DCS) as compared to other milk unions of Rajasthan state. The present study was confined in all thirteen milk collection units of Ganganagar and Bikaner milk unions. Two dairy cooperative societies were randomly selected from each route. This way total 26 dairy cooperatives societies (DCS) were selected with a sample size of 275 respondents. The data were collected through pre-tested structured interview schedule by holding personal interview. The entrepreneurial behavior of dairy farmers was measured with respect to nine dimensions namely innovativeness, achievement motivation, decision making ability, risk orientation, co-ordination ability, planning ability, information seeking behaviour, cosmopoliteness and self-confidence. It was revealed from present investigation that majority of dairy farmers had highest entrepreneurial behaviour towards the innovativeness and decision making ability. Majority of the dairy farmers belonged to medium level of entrepreneurial behaviour, followed by low level of entrepreneurial behaviour of dairy farmers. Therefore, there is a need for providing adequate awareness and training programme for dairy farmers to help them develop into successful entrepreneur.

\section{Introduction}

India occupies the foremost position among the countries of world in respect of livestock.
It accounts for 16 percent of cattle population and 57 per cent of buffalo population of the world. Livestock is the source of various products like milk, meat, bones, horns, skins 
etc, which can be used to produce a variety of products. India is the largest milk producer in world and Rajasthan having second highest position in livestock after Uttar Pradesh in india. Rajasthan shares 11.99 per cent of milk production in India (Anon., 2018-19). Rajasthan Co-operative Dairy Federation has been designed as implementing agency for "Operation Flood" programme in the state. Operation flood programme envisages processing of milk and milk products by the milk union themselves. The advent of "Operation Flood" has made the farmers in rural areas to realize the importance of dairy units as the potential source of additional income and employment. Hence, entrepreneurship development plays important role in dairy enterprise to make dairying as most profitable sector. Entrepreneurship is the central force driving economic activity and prime catalyst in development. Dairy entrepreneurs in rural areas have made a tremendous impact on the agrarian economy. Therefore, role of dairy farmers is very important in dairy industry and socio-economic development of the society (Chaudhari et al., 2007). But the facts remain in the uneven distribution of gains from livestock enterprise across the country. Hence, it forms an essential component in the development. Entrepreneurship is influenced by various socio-economic; personal factors either individually or in combination and the supporting system and the social environment also determines it to some extent. Considering the importance of dairy farming in India and the need of development of entrepreneurship in this sector, the present study was undertaken to assess the status of entrepreneurial behaviour of the dairy farmers in Rajasthan state.

\section{Materials and Methods}

The present study was conducted in 2020 to analyze the entrepreneurial behavior among beneficiaries of Rajasthan Dairy Cooperative Federation (RCDF). It comprised of 21 milk union in Rajasthan state. In North-Western Rajasthan there were 5 milk unions namely Bikaner, Ganganagar, Jodhpur, Nagour and Barmer. Out of these 5 milk unions, only two milk union viz., Ganganagar and Bikaner were purposely selected for study due to reason that these milk unions had higher number of registered Dairy Cooperative Societies (DCS) as compared to other milk unions of Rajasthan state.

There are two districts in Ganganagar milk union, namely Sri Ganganagar and Hanumangarh. Ganganagar milk union of Rajasthan is divided in seven milk collection units, namely Suratgarh, Gharsana, Padampur, Hanumangarh, Nohar, Bhadra and Pallu by the union. Bikaner milk union is divided into six milk collection units, namely Bikaner, Loonkaransar, chattergarh, Khajuwala, Dungarhgarh and Bajju by the union. The present investigation was conducted in all thirteen milk collection units of Ganganagar and Bikaner milk unions. Each milk collection unit consists 4 to 20 milk routes. One milk route was selected randomly from these units. This way thirteen milk routes were selected for the present study. Each milk route consisted of approximately 15 to 57 dairy cooperative societies. Two dairy cooperative societies were randomly selected from each route. This way total 26 dairy cooperatives societies (DCS) were selected. For selection of the respondents from selected cooperative societies, proportionate random sampling procedure was adopted to make a sample size of 275 respondents. Twenty per cent members from each selected DCS were selected applying random technique. Data were collected by personal interview method using structured interview schedule and collected data were analysed by using appropriate statistical tools such as frequency, percentage, mean, standard 
deviation, Spearman's co-efficient of correlation, ranking and analysis of variance.

In the present study, entrepreneurial behaviour of dairy farmers was operationally defined as cumulative outcome of nine components namely, innovativeness, achievement motivation, decision making ability, risk orientation, co-ordination ability, planning ability, information seeking behaviour, cosmopoliteness and selfconfidence.

To analyse the entrepreneurial behaviour of beneficiaries, entrepreneurial behaviour scale developed by Choudhari et al., (2007) was used with slight modification as suggested by experts. Further respondents were categorized into low, medium and high group on all the 9 components of entrepreneurial behaviour.

\section{Results and Discussion}

\section{Entrepreneurial behaviour of beneficiaries}

The entrepreneurial behaviour of beneficiaries was studied and assessed using scale developed by Choudhari et al., (2007) with slight modification as suggested by experts. The entrepreneurial behaviour of beneficiaries comprised of nine components namely, innovativeness, achievement motivation, decision making ability, risk orientation, coordination ability, planning ability, information seeking behaviour, cosmopoliteness and self-confidence. Entrepreneur's profile on these nine dimensions was analyzed by pooling the scores obtained. Detailed data with regards to component wise have been furnished in Table 1 and the same have been interpreted and discussed, as follows:

Appraisal of data given in table 1 revealed that in case of small farmers, 'achievement motivation' had the highest contribution towards entrepreneurial behaviour and ranked first while 'information seeking behaviour' ranked last. The remaining seven components studied were varyingly associated with the entrepreneurial behaviour. Subrahmanyeswari et al., (2007) and Lawrence and Ganguli (2012) also found achievement motivation of small dairy farmers to rank first.

In case of medium category of dairy farmers, highest contribution was found by 'decision making ability', hence it was ranked first whereas 'co-ordinating ability' was found to have minimum contribution and ranked last of all nine components. On the other hand, variables like planning ability, innovativeness, cosmopoliteness, achievement motivation, self-confidence, information seeking behavior and risk orientation contributed significantly towards entrepreneurial behaviour of the farmers (Table 1). The results indicated that farmers perceived more opportunities out of their decision making ability, planning ability, innovativeness and social system, as indicated by association of cosmopoliteness scores.

As far as large category of dairy farmers was concerned, ranking order of entrepreneurial behavior component was different as first rank was secured by 'coordinating ability' of dairy farmers. Further table shows that variables like risk orientation, innovativeness, decision making ability, self-confidence, achievement motivation, cosmopoliteness and information seeking behavior exerted varying degrees of influence on entrepreneurial behaviour. Here planning ability of dairy farmers ranked last. Possible reasons might be that the large dairy respondents were having natural instinct to risk orientation and coordinate actions out of their social system to explore more opportunities for commercial dairy farming which in turn might have resulted in increased benefits and increased self confidence in dairy farming practices. 
Table.1 Component wise entrepreneurial behaviour of dairy farmers $(\mathrm{N}=275)$

\begin{tabular}{|c|c|c|c|c|c|c|c|c|c|}
\hline \multirow[t]{2}{*}{$\begin{array}{l}\text { S. } \\
\text { No. }\end{array}$} & \multirow[t]{2}{*}{$\begin{array}{l}\text { Dimensions of } \\
\text { entrepreneurial } \\
\text { behavior }\end{array}$} & \multicolumn{2}{|c|}{$\begin{array}{c}\text { Small } \\
\text { dairy } \\
\text { farmers } \\
(n=63)\end{array}$} & \multicolumn{2}{|c|}{$\begin{array}{l}\text { Medium } \\
\text { dairy } \\
\text { farmers } \\
(\mathrm{n}=119)\end{array}$} & \multicolumn{2}{|c|}{$\begin{array}{l}\text { Large } \\
\text { dairy } \\
\text { farmers } \\
(n=93)\end{array}$} & \multicolumn{2}{|c|}{$\begin{array}{c}\text { Overall } \\
(\mathrm{N}=275)\end{array}$} \\
\hline & & EBI & Rank & EBI & Rank & EBI & Rank & EBI & Rank \\
\hline 1. & Innovativeness & 54.92 & IV & 63.81 & III & 66.02 & III & 61.58 & I \\
\hline 2. & Achievement motivation & 57.77 & I & 62.99 & V & 59.31 & VI & 60.02 & IV \\
\hline 3. & Decision making ability & 55.20 & III & 67.64 & I & 60.39 & IV & 61.08 & II \\
\hline 4. & Risk orientation & 54.76 & V & 59.10 & VIII & 66.55 & II & 60.14 & III \\
\hline 5. & Co-ordinating ability & 56.98 & II & 48.10 & IX & 66.88 & I & 57.32 & VII \\
\hline 6. & Planning ability & 53.65 & VII & 64.70 & II & 44.23 & IX & 54.19 & VIII \\
\hline 7. & $\begin{array}{l}\text { Information seeking } \\
\text { behavior }\end{array}$ & 41.43 & IX & 61.84 & VII & 55.91 & VIII & 53.06 & IX \\
\hline 8. & Cosmopoliteness & 54.62 & VI & 63.36 & IV & 57.88 & VII & 58.62 & V \\
\hline 9. & Self confidence & 51.32 & VIII & 62.43 & VI & 59.85 & V & 57.87 & VI \\
\hline & Total & 53.40 & & 61.55 & & 59.67 & & 58.21 & \\
\hline
\end{tabular}

$\mathrm{EBI}=$ Entrepreneurial Behaviour Index

Table.2 Classification of respondents on the basis of their entrepreneurial behavior $(\mathrm{N}=275)$

\begin{tabular}{|c|c|c|c|c|c|c|c|c|c|}
\hline \multirow[t]{2}{*}{$\begin{array}{l}\text { S. } \\
\text { No. }\end{array}$} & \multirow[t]{2}{*}{$\begin{array}{l}\text { Level of } \\
\text { entrepreneurial } \\
\text { behavior }\end{array}$} & \multicolumn{2}{|c|}{$\begin{array}{l}\text { Small } \\
\text { dairy } \\
\text { farmers } \\
(n=63)\end{array}$} & \multicolumn{2}{|c|}{$\begin{array}{l}\text { Medium } \\
\text { dairy } \\
\text { farmers } \\
(n=119)\end{array}$} & \multicolumn{2}{|c|}{$\begin{array}{l}\text { Large } \\
\text { dairy } \\
\text { farmers } \\
(n=93)\end{array}$} & \multicolumn{2}{|c|}{$\begin{array}{c}\text { Overall } \\
(\mathrm{N}=275)\end{array}$} \\
\hline & & $\mathbf{F}$ & $\%$ & $\mathbf{F}$ & $\%$ & $\mathbf{F}$ & $\%$ & $\mathbf{F}$ & $\%$ \\
\hline 1. & Low $(<58)$ & 19 & 30.16 & 18 & 15.13 & 21 & 22.58 & 58 & 21.09 \\
\hline 2. & Medium (58 to 86 ) & 39 & 61.90 & 80 & 67.23 & 63 & 67.74 & 182 & 66.18 \\
\hline 3. & $\operatorname{High}(>86)$ & 05 & 07.94 & 21 & 17.65 & 09 & 09.68 & 35 & 12.73 \\
\hline
\end{tabular}

Mean $=71.77$, S.D. $=14.38, \mathrm{~F}=$ Frequency, $\%=$ Per cent

In overall analysis 'innovativeness' of dairy farmers had highest contribution (61.58 EBI) towards entrepreneurial behaviour with its first rank. While decision making ability, risk orientation, achievement motivation, cosmopoliteness, self-confidence, coordinating ability and planning ability of dairy farmers were at II, III, IV, V, VI, VII and VIII ranks, respectively. As in each category of dairy farmers, 'information seeking behaviour' of dairy farmers had the last rank. Farmers of all the three categories either were not be able to integrate themselves in existing network of information or they were lacking awareness about it, which might be the reason that this component to rank last in relative contribution towards entrepreneurial behaviour. Subrahmanyeswari et al., (2007) and Lawrence and Ganguli (2012) reported that self confidence was the most important component in predicting entrepreneurial behaviour of dairy owners.

\section{Overall Level of entrepreneurial behaviour of dairy farmers}

To get an overview of the entrepreneurial level, the respondents were classified into three categories using mean (71.77) and standard deviation (14.38). The dairy farmers 
who scored below 58 entrepreneurial behaviour scores were grouped in low entrepreneurial behaviour level, the dairy farmers who scored from 58 to 86 were grouped under medium entrepreneurial behaviour level and those who secured above 86 entrepreneurial behaviour score were categorized under high entrepreneurial behaviour level.

It could be observed from the data in table 2 that most of dairy farmers $(66.18 \%)$ belonged to medium level entrepreneurial behaviour, followed by 21.09 per cent of dairy farmers who belonged to low level of entrepreneurial behaviour, whereas only 12.73 per cent of dairy farmers belonged to high level of entrepreneurial behaviour.

The data in table 2 further indicated that majority of small (61.90\%), medium $(67.23 \%)$ and large $(67.74 \%)$ dairy farmers belonged to medium level of entrepreneurial behaviour, whereas 30.16 per cent small, 15.13 per cent medium and 22.58 per cent large dairy farmers were having low level of entrepreneurial behavior. Whereas, 7.94 per cent small, 17.65 per cent medium and 9.68 per cent large dairy farmers belonged to high level of entrepreneurial behaviour.

Overall study of entrepreneurial behaviour of dairy farmers revealed that majority (66.18 $\%$ ) of respondents had medium level of entrepreneurial behaviour which might be due to medium level of innovativeness, achievement motivation, decision making ability, information seeking behaviour and cosmopoliteness among the respondents. Similar observations were reported by Kiran et al., (2012), Lawrence and Ganguli (2012) and Singh et al., (2013).

It can be concluded from the above findings that majority of dairy farmers $(66.18 \%)$ had medium level of entrepreneurial behaviour, followed by 21.09 per cent of dairy farmers who belonged to low level of entrepreneurial behaviour, whereas only 12.73 per cent of dairy farmers belonged to high level of entrepreneurial behaviour. Majority of small (61.90\%), medium (67.23\%) and large $(67.74 \%)$ dairy farmers belonged to medium level of entrepreneurial behaviour, whereas 30.16 per cent small, 15.13 per cent medium and 22.58 per cent large dairy farmers were having low level of entrepreneurial behavior. Whereas, 7.94 per cent small, 17.65 per cent medium and 9.68 per cent large dairy farmers belonged to high level of entrepreneurial behavior. Therefore, high level of entrepreneurial behavior was very less among the selected dairy farmers. Most of them belonged to medium level of entrepreneurial behavior.

While the result related to component-wise entrepreneurial behavior revealed that among the small dairy farmers, 'achievement motivation' had the highest contribution towards entrepreneurial behaviour and ranked first while 'information seeking behaviour' ranked last. Further, in medium dairy farmers, highest contribution was found by 'decision making ability', thus it was ranked first whereas 'co-ordinating ability' was found to have minimum contribution and ranked last of all nine components. Whereas, the large dairy farmers were concerned, ranking order of entrepreneurial behavior component was different as first rank was secured by 'coordinating ability' of dairy farmers. Thus, there is a need to impart training to dairy farmers to help become successful on different aspects of entrepreneurial behavior.

\section{References}

Anonymous, 2018-19.National Dairy Development Board, Annual report 2018-19.

Chaudhari, R.R., Hirevenkanagoudar L.V., 
Hanchinal S.N. and Mokashi A.N. (2007). A scale for measurement of entrepreneurial behavior of dairy farmers. Karnataka J. Agril. Sci. 20(4): 792-796.

Kiran, Dipak De, Gupta, B. K. and Pandey, D. K. 2012. Entrepreneurial Behaviour in Rural Women of Sultanpur District of Uttar Pradesh.Indian Res.J.Ext.Edu., 12(2): 29-33.

Lawrence, C. and Ganguli, D. 2012. Entrepreneurial behaviour of dairy farmers in Tamil Nadu. Indian Res. J. Ext. Edu., 12(1):66-70.

Singh, P., Sharma, K. C. and Dahiya, N. S. 2013.Entrepreneurial behaviour of dairy farmers in western Rajasthan. Veterinary Practitioner, 14(2):390-393.

Subramanyeswari, B., Reddy, K. V. and Rao, B. S.2007. Entrepreneurial behavior of rural women farmers in dairying: a multidimensional analysis. Livestock Research for Rural Development. 19(1):1-9.

\section{How to cite this article:}

Dwarka Prasad, J. P. Lakhera, Seema Tyagi, Diksha Sharma and Sunil Kumar. 2021. Entrepreneurial Behaviour of Dairy Farmers in North-Western Rajasthan. Int.J.Curr.Microbiol.App.Sci. 10(02): 1111-1116. doi: https://doi.org/10.20546/ijcmas.2021.1002.130 